\title{
Sensitivity Study of Design Parameters for a Fuel Cell Powered Multirotor Drone
}

\author{
Jørgen Apeland ${ }^{1,2}$ (D) Dimitrios G. Pavlou ${ }^{1}$ (D) $\cdot$ Tor Hemmingsen $^{1}$ (B)
}

Received: 1 October 2020 / Accepted: 9 March 2021 / Published online: 15 April 2021

(C) The Author(s) 2021

\begin{abstract}
The use of multirotor drones for industrial applications is accelerating, and fuel cell based propulsion systems are highlighted as a promising approach to improve endurance - one of the current main limitations. Due to multirotor drones' unique requirements, careful system design is needed to maximize the performance advantage. In this work a sensitivity analysis that quantifies the impact of central system parameters for an X8 multirotor drone with a $2 \mathrm{~kW}$ fuel cell hybrid system is presented and discussed. Thrust stand measurements identified a 20-30\% efficiency loss from the coaxial configuration, and a 'single' configuration can reduce power consumption by $700 \mathrm{~W}$ at $25 \mathrm{~kg}$ take-off mass. Thus, a smaller fuel cell system can be used, giving an additional $1 \mathrm{~kg}$ mass saving and 75-140 W power reduction. Peak endurance is found at a 0.67 energy system weight fraction, and if batteries are improved from $180 \mathrm{Wh} / \mathrm{kg}$ to $350 \mathrm{Wh} / \mathrm{kg}$, the energy system mass threshold from where fuel cells are superior rises from $7.4 \mathrm{~kg}$ to $8.5 \mathrm{~kg}$. At $700 \mathrm{bar}$, a $3 \mathrm{~L}$ hydrogen cylinder can replace a $6 \mathrm{~L}$ at $300 \mathrm{bar}$, provide a 72 -min endurance, and is the preferred option to reach minimum system volume. This work provides guidance in early conceptual stages and insights on how fuel cell based powerplants for multirotors can be improved and optimized to increase their value proposition. Further research can expand the work to cover other system variations and do experimental testing of system performance.
\end{abstract}

Keywords Fuel cell $\cdot$ Hybrid power $\cdot$ Multirotor drone $\cdot$ Performance threshold $\cdot$ Sensitivity analysis

$\begin{array}{ll}\text { Abbreviations } \\ \text { BEMT } & \text { Blade Element Momentum Theory } \\ \text { BoP } & \text { Balance of Plant } \\ \text { CONOPS } & \text { Concept of Operations } \\ \text { DC } & \text { Direct Current } \\ \text { DMFC } & \text { Direct Methanol Fuel Cell } \\ \text { EASA } & \text { European Aviation Safety Agency } \\ \text { FC } & \text { Fuel Cell } \\ \text { FCHS } & \text { Fuel Cell Hybrid System } \\ \text { LHV } & \text { Lower Heating Value }\end{array}$

Jørgen Apeland

ja@nordicunmanned.com

Dimitrios G. Pavlou

dimitrios.g.pavlou@uis.no

Tor Hemmingsen

tor.hemmingsen@uis.no

1 University of Stavanger, Kjell Arnholms gate 41, Stavanger 4021, Norway

2 Nordic Unmanned AS, Rådhusgata 3, Sandnes 4306, Norway
LiPo
PEM
SOFC
SORA
UAV
Lithium-Polymer (battery)
Proton Exchange Membrane
Solid Oxide Fuel Cell
Specific Operation Risk Assessment
Unmanned Aircraft Vehicle

\section{Introduction ${ }^{1}$}

There is an increase in the industrial use of unmanned aircraft systems and interest in how they can create value through more cost-efficient, time-saving, and higher quality inspections and services. Multirotor drones have the advantage of a small take-off and landing footprint, reasonable positioning control, can hover in the same geographical location, and carry payloads at both low and high velocities. These multirotor drones can typically have a take-off mass of up to $25 \mathrm{~kg}$ and a payload capacity of $5 \mathrm{~kg}$. To improve performance and

\footnotetext{
${ }^{1}$ Parts of this paper was presented and published in the Proceedings of the 2020 International Conference on Unmanned Aircraft Systems, Athens, Greece [5].
} 
achieve a higher mission endurance and range, research efforts have been focused on the power plant.

The most common energy source used is pouch cell lithiumion batteries, often referred to as LiPo batteries, with a specific energy of 130-200 Wh/kg [1]. However, above a certain threshold, adding more batteries will not increase the endurance due to the increased power consumption from the added mass. To further improve the endurance, the power plant's specific energy must be improved - more energy must be added without adding more mass. Fuel cell hybrid systems can provide a specific energy of $250-540 \mathrm{Wh} / \mathrm{kg}$ [2] on a power plant level and can give a better endurance than batteries.

Early research has focused on fixed-wing UAVs [3, 4]. As multirotor drones have more power-intensive and dynamic load profiles, the fuel cell hybrid systems require a higher nominal stack power and a higher degree of hybridization than fixed-wings. Integration and use on multirotor drones are now becoming a highly relevant research field due to two main factors: 1) lightweight fuel cell systems with high enough performance are now becoming commercially available, creating supply, and 2) multirotor drones with an adequate energy system capacity is now emerging and becoming more popular for industrial use, creating a demand.

There is limited research exploring fuel cell hybrid system design and optimization for multirotor drones in the $25 \mathrm{~kg}$ take-off mass and power range. This research should be valuable for the fuel cell drone community as it provides useful insights into central parameters and performance thresholds that can guide system optimization and improvements. This is essential for unlocking the full potential of the technology and for ensuring further technology adoption.

This sensitivity analysis investigates the impact on drone performance from several relevant system parameters. Experimental data for a relevant propulsion system is presented and used to develop an empirical power consumption model, which is then used in a sensitivity study to ensure a high validity. Factors like propulsion system configuration and efficiency, take-off mass and energy system mass fraction and energy perspectives concerning improved battery and hydrogen storage performance are investigated. For context, the current state-of-technology and some broader perspectives on fuel cell adoption are also presented and discussed.

\section{State-of-Technology}

\subsection{Fuel Cell Hybrid Systems}

Lightweight proton exchange membrane (PEM) fuel cells that run on compressed hydrogen are the most technologically mature and most frequently used type for UAV applications, but there are a few options like DMFC (direct methanol fuel cells) and SOFC (solid oxide fuel cells). The different options are based on the same basic electrochemical principles, but they operate in different temperature regimes, use different materials, and have different performance characteristics and fuel tolerance [5-7].

In PEM fuel cells, the electrolyte is a polymer membrane that protons can move through, and a platinum catalyst is used to achieve sufficient reaction rates at low temperatures. They have a relatively high power density, have a short start-up time, a relatively good transient load response, and have a high technical maturity. They require a high hydrogen purity (99.999\%) and can be contaminated by carbon monoxide (CO) and hydrogen sulfide $\left(\mathrm{H}_{2} \mathrm{~S}\right)$.

The power demand for multirotor drones are generally higher than for fixed-wing UAVs, and the load profile is more dynamic [8]. Thus, the fuel cells must have higher nominal power and have a more active hybrid management system with a larger battery component. This increases the mass of the power system and introduces some additional challenges.

In a fuel cell hybrid system (FCHS), the fuel cell is the primary power source, and a 'hybrid' battery is the secondary power source (Fig. 1). Ideally, the fuel cell provides continuous power, and the battery gives the system a better response to dynamic loads, handle peak loads, provides redundancy, and serves as an energy buffer for emergency landings. The sub-systems of a hybrid fuel cell system are (1) Fuel Cell Stack, (2) Balance of Plant (BoP), (3) Hybrid Battery, and (4) Hydrogen Storage. BoP includes control electronics, power management, and thermal and humidity management

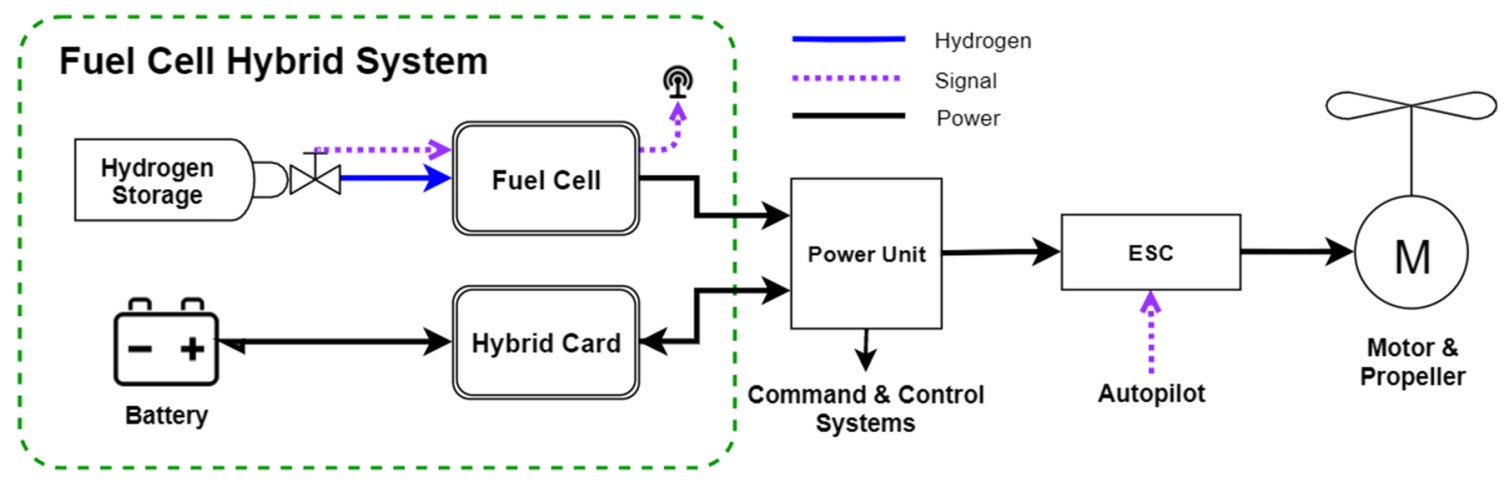

Fig. 1 Simplified layout of a fuel cell hybrid system based multirotor propulsion system 
Table 1 Fuel cell systems [2, 9-13]

\begin{tabular}{llllll}
\hline Vendor & System & $\begin{array}{l}\text { Power } \\
{[\mathrm{W}]}\end{array}$ & $\begin{array}{l}\text { Mass } \\
{[\mathrm{g}]}\end{array}$ & $\begin{array}{l}\text { Specific Power } \\
{[\mathrm{W} / \mathrm{kg}]}\end{array}$ & Cooling \\
\hline HES & A-1000 (HV) & 1000 & 1800 & 556 & Air \\
& A-1500 & 1500 & 2800 & 536 & $\begin{array}{l}\text { Air } \\
\text { Intelligent Energy }\end{array}$ \\
& A-2000 & 2000 & 4380 & 457 & Air \\
& 650 FCPM & 650 & 810 & 802 & Air \\
Ballard & 800 FCPM & 800 & 930 & 860 & Air \\
& 2.4 FCPM & 2400 & 3250 & 738 & Air \\
MMC & FCair 600 & 600 & 1800 & 333 & Liquid \\
Doosan & FCair 1200 & 1200 & 4000 & 300 & Liquid \\
Spectronik & H1 & 1000 & 1700 & 588 & Air \\
& DP30 & 2600 & 3400 & 764 & Air \\
& Protium-1000 & 1000 & 5755 & 174 & Liquid \\
& Protium-2000 & 2000 & 7585 & 264 & Liquid \\
& Protium-2500 & 2500 & 9020 & 277 & Liquid \\
\hline
\end{tabular}

systems. The fuel cell stack configuration determines the nominal power. The system has a certain empty mass, and it is the hydrogen storage and the hybrid battery that determines the amount of energy in the system. When comparing system performance to battery alternatives, it is essential that the mass of the complete power-system is considered.

Commercially available fuel cells from some of the most relevant actors in the market are listed in Table 1. These fuel cells are found in most commercially available fuel cell powered UAVs and demonstrator projects. When comparing fuel cell systems, it must be noted that they may operate at different voltages, and different hybrid system configurations provide different dynamic load performance.

\subsection{Fuel Cell Powered Multicopters and Demonstrators}

The Hycopter from HES is powered by a $1500 \mathrm{~W}$ fuel cell and has a maximum take-off mass of $15 \mathrm{~kg}$ [9]. It is stated to be capable of a $3.5 \mathrm{~h}$ endurance and reaching a $700 \mathrm{Wh} / \mathrm{kg}$ system-level specific energy. In 2019, a Hycopter was provided to the U.S. Navy to assess the feasibility of using fuel cell systems onboard naval platforms [14].

Intelligent Energy is primarily targeting third party integrators. With the power path module, they can achieve a range of nominal power levels $[15,16]$. Together with strategic partners, they have integrated their power modules on different multirotor drones and demonstrated relevant use-cases and performance benchmarks. The $800 \mathrm{~W}$ fuel cell power module was integrated with the e-Drone Zero from Skycorp and the SENSUS drone from ISS Aerospace [2]. In project RACHEL, a 70 min flight endurance with a $5 \mathrm{~kg}$ payload was demonstrated [17]. The maximum take-off mass was below $20 \mathrm{~kg}$, and the original usable flight time for that drone was $12 \mathrm{~min}$. They used a $6 \mathrm{~L}$ vessel with compressed hydrogen at $30 \mathrm{MPa}$. Together with MetaVista, a liquid hydrogen company, an endurance of $10 \mathrm{~h}$ and $50 \mathrm{~min}$ was demonstrated [17]. A $650 \mathrm{~W}$ fuel cell was used, and the cryogenic hydrogen storage contained $390 \mathrm{~g}$ hydrogen. In April 2019, it was reported that the record was further improved to $12 \mathrm{~h}, 7 \mathrm{~min}$, and $22 \mathrm{~s}$, using an $800 \mathrm{~W}$ fuel cell, which at that time was a new Guinness World Record [18].

The FCAir 1200 fuel cell from Ballard has been integrated into the H2-6 from BFD Systems [11]. The drone weighs $12 \mathrm{~kg}$, has a $2 \mathrm{~kg}$ payload capacity, and a $90-\mathrm{min}$ endurance. One unique feature of this drone is that the radiator is located on the arms for efficient cooling, as it is a liquid-cooled fuel cell. Ballard has been active in educating the industry about fuel cell powered drones and has published several useful white papers [19-22].

Doosan Mobility Innovation has developed the DP30 Powerpack [12], an integrated fuel cell power module that includes all the associated components and can be fitted on any suitable airframe. They also provide the DS30, an octocopter where the power module is integrated. It has a payload capacity of $5 \mathrm{~kg}$ and a maximum take-off mass of $24.9 \mathrm{~kg}$. In 2019, the DS30 demonstrated a $69 \mathrm{~km}$ medical drone delivery beyond visual line of sight [23]. Doosan has also initiated a project with Skyfire Consulting to establish emergency response and routine inspection routines for a major U.S. gas pipeline [24]. During CES 2020 (Consumer Electronics Show), their fuel cell solutions won two awards; "Best of Innovation" in the Drones and Unmanned Systems category, and an "Honoree" award in the sustainability, Eco-design \& Smart Energy Category [25].

\section{Reference System and Performance}

\subsection{Fuel Cell Hybrid System and Multicopter}

The Staaker BG-200 FC multirotor drone (Fig. 2) is used as a reference platform [26]. It has an X8-configuration with 28" 




Fig. 2 Staaker BG-200 FC from Nordic Unmanned with the reference fuel cell hybrid system installed

propellers and is designed for a $25 \mathrm{~kg}$ maximum take-off mass. The empty mass is $8.5 \mathrm{~kg}$, including the airframe and all fixed components, but not the power plant or payload. The standard battery alternative weighs $8 \mathrm{~kg}$ and has a specific energy of about $180 \mathrm{Wh} / \mathrm{kg}$.

The reference fuel cell hybrid system (FCHS) used in the sensitivity analysis consists of two 65 cell fuel cell stacks that can provide a nominal power of $2 \mathrm{~kW}$ combined, an 11S LiPo hybrid battery (16 Ah), and a 7.2 L hydrogen cylinder [27]. The Class IV carbon fiber cylinder can store $150 \mathrm{~g}$ hydrogen at $300 \mathrm{bar}$ and weighs $2.8 \mathrm{~kg}$. The total mass of this fuel cell hybrid system is $12.2 \mathrm{~kg}$, and the specific energy is $242 \mathrm{Wh} /$ $\mathrm{kg}$. A range of Class IV cylinders from Composite Technical Systems SpA is used to present alternative system configurations in the sensitivity analysis [28].

Aerostak A-1000 fuel cells from HES is used in a passive parallel hybrid configuration, where the power split between the fuel cells and battery is controlled by the DC-bus voltage. The fuel cell voltage is initially higher than the battery voltage. As the power demand increase, the fuel cell voltage will drop to a certain threshold voltage at max power, which is matched with the battery voltage. From that point, the battery will provide all additional power supply, and the fuel cell will operate at a constant output, as illustrated in Fig. 3. That is as long as the battery capacity and discharge characteristics can manage the additional load. In low power demand situations, the fuel cell can charge the battery. This is controlled by the "hybrid card' (Fig. 1), which has a DC-DC converter and diodes that limits charging voltage and current. Similar hybrid systems are investigated in $[29,30]$.

\subsection{Gross Endurance}

Gross endurance is effective for assessing the relative performance of various energy system options [31]. As presented in [27], the flight endurance is found by dividing the effective energy $\mathrm{E}$ on the power consumption P. By assuming a constant fuel cell efficiency and using the average power consumption, the model represents static hovering conditions and gives the gross endurance. The effective energy is the actual energy that can be utilized for propulsion, considering a relevant battery depth of discharge and hydrogen usage. The power consumption is a function of the take-off mass and accounts for the energy system mass. Even though the specific energy $[\mathrm{Wh} / \mathrm{kg}]$ can be used in a basic comparison of energy systems, the gross endurance gives a better representation of the impact different energy systems have on both energy and mass through the power consumption. In contrast to gross endurance, net endurance considers more dynamic conditions and can provide more accurate range and endurance estimates for specific mission profiles. This is more useful in detailed system design and in establishing an operational envelope.

\subsection{Performance Threshold between FCHS and Batteries}

Figure 4 is established in [27] and applies to the reference drone and reference fuel cell hybrid system (FCHS). It has
Fig. 3 The three main states of the hybrid system, where the fuel cell is 1) charging the battery, 2) providing power to a load and potentially charging, and 3) the fuel cell is operating at max power, and the battery is providing the remaining power

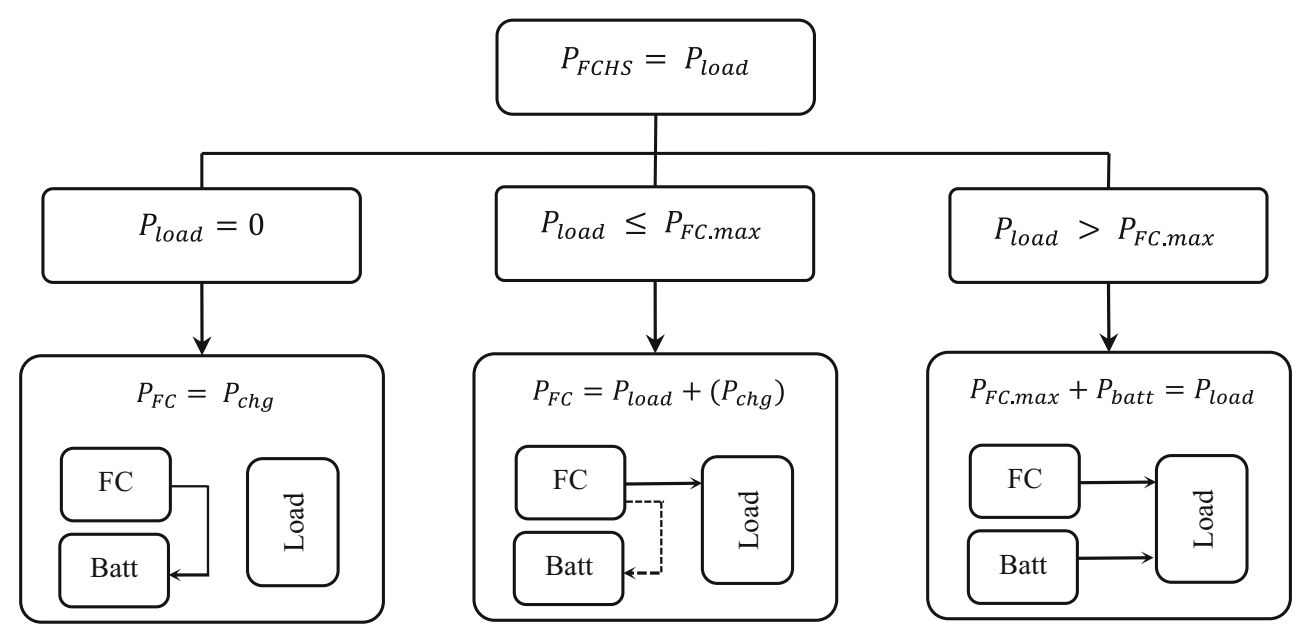


Fig. 4 Gross endurance plot for the reference fuel cell hybrid system and multirotor drone with a range of cylinder options and reference curves for different specific energies. The cylinders used are $2 \mathrm{~L}, 3 \mathrm{~L}, 6 \mathrm{~L}, 6.8 \mathrm{~L}$, $7.2 \mathrm{~L}$, and $9 \mathrm{~L}$ with hydrogen at 300 bar. Note that in practice, there is a lower cut-off limit given by the power required for take-off

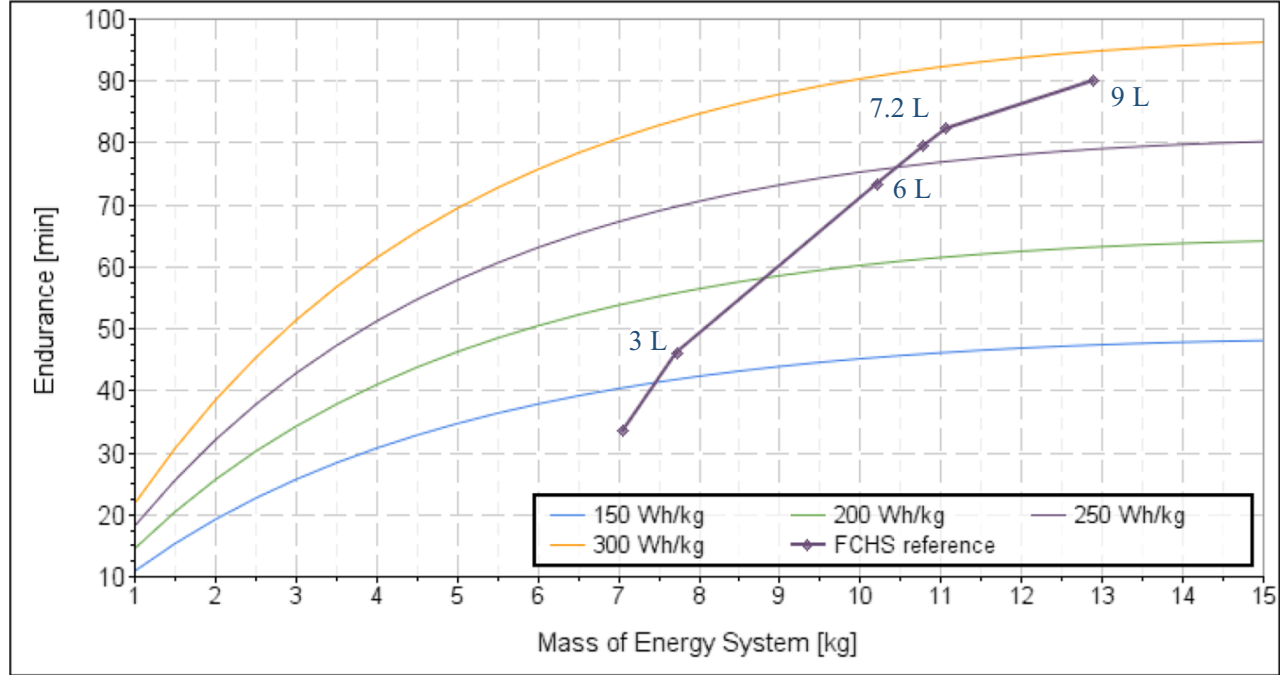

been expanded to include curves for a range of constant specific energies, which serve as useful references. The graphs show how gross endurance is affected by the specific energy and total energy system mass. A range of FCHS system configurations is included, making it simple to identify the performance threshold for when the best endurance can be achieved. The $150 \mathrm{Wh} / \mathrm{kg}$ curve is close to the effective specific energy for the standard LiPo-batteries, which shows that the FCHS will give a better gross endurance above a threshold mass of about $7.5 \mathrm{~kg}$. This case and underlying models are used as a basis for this sensitivity study to explore how various system parameters affect the relative performance of battery and fuel cell systems, and identify the impact on the performance threshold.

It can be seen that the endurance improves rapidly at low energy system mass and that this tendency continues longer for the higher specific energy curves. At some point, however, the curves flatten and will start to decrease. The propulsion system load response determines these characteristics. At some point, the energy system's added mass increases the propulsion power so that the added energy does not compensate and give a net endurance gain. This typically happens at high propulsion system utilization, where the propulsion efficiency becomes poor.

The diagram also emphasizes a significant difference between batteries and FC hybrid systems. Batteries have constant specific energy, so the mass and energy scale linearly. The power is coupled with the energy capacity through the discharge rate of the battery. For FCHS, power and energy are decoupled, and the specific energy is not constant. An FCHS with a given power rating has a certain empty weight before any energy is added to the system. Hydrogen storage has a relatively high specific energy of typically 600 to $900 \mathrm{Wh} / \mathrm{kg}$, so the overall energy system specific energy is not constant but improves rapidly as more hydrogen is added. From this, it is clear that FCHS are most competitive when the relevant drone has a certain energy system mass, and a certain amount of hydrogen can be stored. For low mass energy systems, batteries will, in most circumstances, give the best performance.

\section{Sensitivity Analysis}

A fundamental condition for using a Fuel Cell Hybrid System (FCHS) to power a multirotor drone is that the endurance will be better than when it is powered by batteries. Next, a sensitivity analysis takes the gross endurance threshold analysis one step further by investigating how central system parameters affect the relative performance between batteries and a fuel cell based power plant. A breakdown of several central system parameters is provided in Fig. 5. An empirical power consumption model is developed and used, which improves the validity of the analysis. The sensitivity study can provide valuable input for system designers and for guiding improvements and optimization efforts.

\subsection{Propulsion System Modelling}

\subsubsection{Analytic Model}

The propulsion system determines how efficiently the electric power is converted into vertical thrust. It can be useful to have an analytic model that is general and requires as few parameters as possible so that it easily can be used to compare a range of options. One of the most basic models is based on the momentum theory. As derived in [27], the propulsion power for a multirotor drone with $\mathrm{X} 8$ configuration is: 


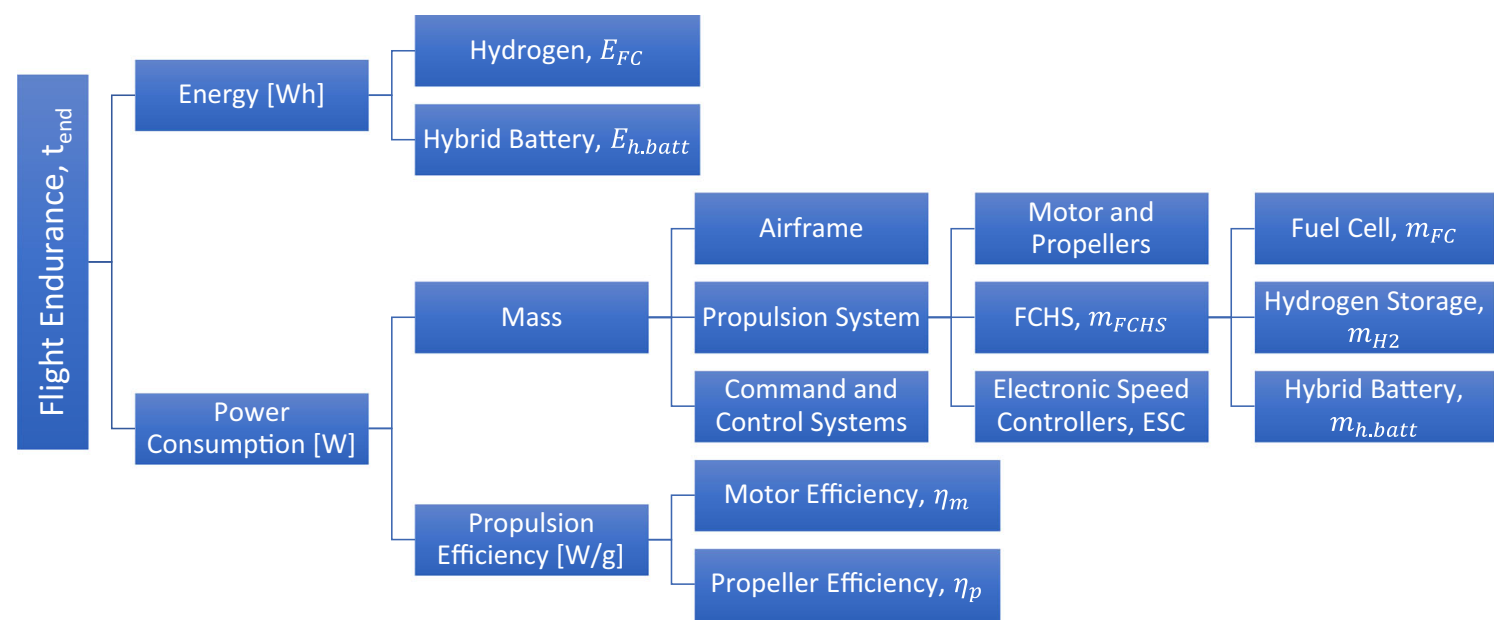

Fig. 5 Breakdown of the most significant system parameters that impact multirotor drone flight endurance

$P_{\text {TOM }}\left(m_{\text {TOM }}\right)=\kappa_{\text {int }} \frac{\left(m_{T O M} \cdot g\right)^{3 / 2}}{2 \sqrt{0.5 \cdot \rho_{\text {air }} \cdot \pi \cdot D_{\text {prop }}^{2}}}$

where $D_{\text {prop }}$ is the propeller diameter, $\rho_{\text {air }}$ is the density of air, $m_{T O M}$ is the take-off mass, and $\kappa_{i n t}$ is the coaxial efficiency factor. This can typically be $1.22,1.28$, or 1.41 , depending on the assumptions made [32]. The advantage of this model is that the input parameters are easy to identify. The coaxial propulsion efficiency is somewhat represented, but the accuracy might not be known, so the model should be calibrated and validated.

Blade element momentum theory (BEMT) is another modeling approach [32]. It is based on momentum theory, but it incorporates some propulsion system-specific parameters and can be identified by numerical methods or experiments.

\subsubsection{Experimental Data and Empirical Model}

The overall propulsion efficiency is determined by the motor efficiency and how well the electric power is converted to mechanical power at the propeller shaft, and propeller efficiency through how well the mechanical power is converted to thrust through the propeller's aerodynamic performance. Assuming a motor efficiency $\eta_{m}=85 \%$, which is considered to be very good, and a propeller efficiency $\eta_{p}=80 \%$, a decent overall propulsion system efficiency is 68\% [33]. Many factors can influence the efficiency, and they typically have a narrow operating range with optimal performance. The best way to capture the inefficiencies and get accurate performance data is to test and measure the actual propulsion system. This can be done by carrying out test flights and analyzing the power consumption data or by running the propulsion system in a thrust stand.

Experiments were carried out in a thrust stand using a propulsion system similar to the reference drone: U8II KV100 motors and 28" propellers from T-motor [34]. The measurement accuracy is $\pm 0.5 \%$ on thrust and voltage, and $+/ 1 \%$ on electric current [35]. Data was collected for a single and coaxial propeller configuration with a face-to-face setup and a $109 \mathrm{~mm}$ propeller separation. There is a back-to-back configuration on the drone, but the relative propeller motion is similar to the drone.

The experimental data curves in Fig. 6 are scaled to represent the complete drone propulsion system. The single motor measurements are multiplied by eight, and the coaxial data is multiplied by four. The momentum theory reference curves are calculated with Eq. (1) and use coaxial compensation factors of 1.22 and 1.41 .

According to the experimental data, the coaxial inefficiency is $20 \%$ at low thrust values and increases to $30 \%$ at $25 \mathrm{~kg}$ thrust, representing a $700 \mathrm{~W}$ power difference. Thus, the momentum theory coaxial compensation factors are close, but they underestimate the actual consumption, as seen in the plot. This can lead to an inaccurate power consumption response to mass changes and affect the sensitivity analysis accuracy.

Through curve fitting for the coaxial experimental curve, an empirical equation for estimating the power consumption of the X8 reference drone as a function of take-off mass is provided in Eq. (2). The power is given in W, and the take-off mass $m_{T O M}$ unit is $\mathrm{kg}$, with a validity interval of 0 to $25 \mathrm{~kg}$.

$P_{\exp }\left(m_{\text {TOM }}\right)=2.3369 m_{\text {TOM }}^{2}+64.417 m_{\text {TOM }}$

As demonstrated, experimental data can be used to establish empirical performance models or be used to calibrate and validate analytic models. Accurate propulsion power data is vital for achieving high accuracy when determining an operational envelope or in power plant design and sizing. It should be noted that this data represents static hover conditions and that other parasitic power draw that can occur. When in flight, the turbulence can be lower as more fresh air is introduced, improving the propulsion efficiency [36]. Mapping of in- 

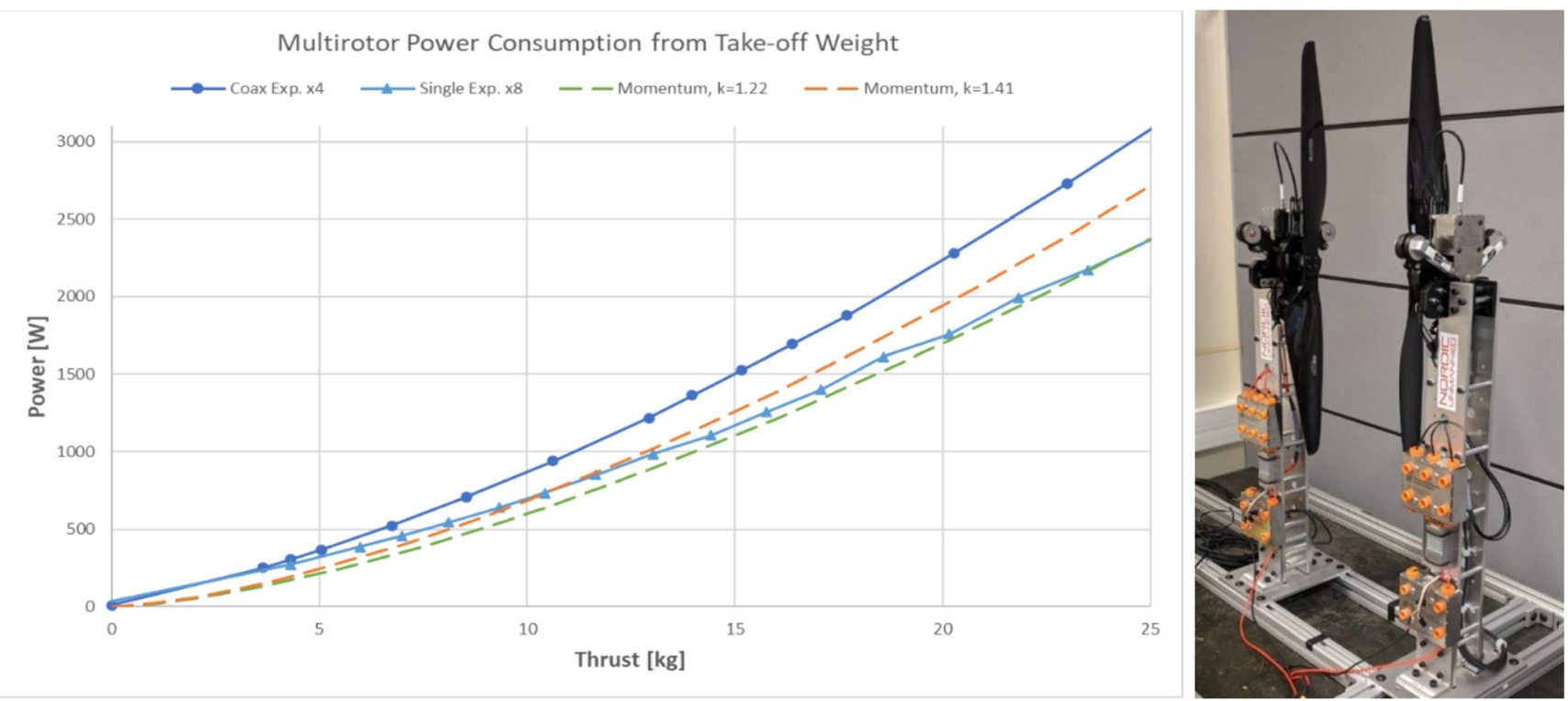

Fig. 6 Experimental and analytic data on the power consumption for an $\mathrm{X} 8$ multirotor drone, with $28^{\prime \prime}$ propellers. The experimental data is collected using an RCbenchmark 1780 series thrust stand (right) at the
University of Stavanger, using coaxial and single rotor setups. Momentum theory (Eq. 1) is used to establish the analytic curves

propeller experimental data, and the X8 curve on the Eq. (2) model.

The S8 configuration will give a $27 \%$ improvement in gross endurance from the $\mathrm{X} 8$ configuration, which corresponds with the 20-30\% propulsion efficiency loss associated with the coaxial configuration. The $\mathrm{S} 6$ configuration gives a $15 \%$ increase in endurance from the X8.

Based on airframe sizing equations [37], an S8 multicopter with 28 " propellers would have to be $2.2 \mathrm{~m}$ in diameter, compared to the $1.2 \mathrm{~m}$ of the $\mathrm{X} 8$ version. A hexacopter also using the 28 " propellers would have a $1.7 \mathrm{~m}$ diameter. If the hexacopter's overall size is limited to that of the X8, the maximum propeller diameter is $20^{\prime \prime}$. Airframe size is an important factor to consider when assessing configurations, as it can have a large impact on the utility.
Fig. 7 Gross endurance for the reference FCHS system with different propulsion system configurations. The overall propulsion efficiency $(\mathrm{g} / \mathrm{W})$ is established from thrust stand measurements and the required propeller thrust for each of the configurations




At a $25 \mathrm{~kg}$ take-off mass, assuming a uniform distribution, each motor must provide $3.125 \mathrm{~kg}$ thrust, and the propeller disc-loading is $78.6 \mathrm{~N} / \mathrm{m}^{2}$. The thrust efficiency is then $10.5 \mathrm{~g} /$ $\mathrm{W}$ for the $\mathrm{S} 8$ configuration, and $8 \mathrm{~g} / \mathrm{W}$ for the $\mathrm{X} 8$ configuration. The $\mathrm{S} 6$ propellers have to provide $4.1 \mathrm{~kg}$ thrust, have a disc loading of $105 \mathrm{~N} / \mathrm{m}^{2}$, and a propulsion efficiency of 9.22 $g / W$. Due to a $25 \%$ lower propeller area, each motor has to work at a higher throttle where the overall efficiency is lower. The 20" S6 configuration would have a disc loading of $209 \mathrm{~N} /$ $\mathrm{m}^{2}$. The propeller area for this configuration is only $50 \%$ that of the octo-configurations, and while the propeller area is reduced, the same thrust must be generated from a lower propeller area. To achieve that at an optimal efficiency, another propeller and motor combination will have to be used.

Many factors influence the overall propulsion efficiency. In general, larger propeller diameters give a higher propeller efficiency [33]. The number of motors determines the required thrust, and the disc loading is determined by the propeller size. The propeller pitch and optimal angular velocity are central parameters, and the propeller torque at the relevant thrust level must be matched with the ideal motor operating torque. Other aerodynamic factors that are influenced by the configuration is the efficiency loss due to vertical airflow interaction between coaxial propellers and horizontal separation to avoid overlapping airflows.

The overall propulsion efficiency is especially relevant when a hybrid power plant is used because it impacts the power sizing of the system. If the drone can lift the same load at a lower power level, it might allow for a smaller and lighter fuel cell system and hybrid battery. With a fuel cell specific power of $738 \mathrm{~W} / \mathrm{kg}$, the $700 \mathrm{~W}$ efficiency loss between an S8 and $\mathrm{X} 8$ configuration at $25 \mathrm{~kg}$ thrust can give a $0.95 \mathrm{~kg}$ mass saving that will further improve endurance.

However, it should be noted that the different configurations have a different number and type of arms and motors, which will affect the drone empty mass and give a secondary endurance or payload capacity impact. The maneuverability and responsiveness are also influenced. Selecting the ideal configuration can be challenging and will depend on the operational requirements. An X8 multicopter has some redundancy and smaller overall size, making it more practical to transport and store at the cost of a less efficient propulsion system. However, this section has shown that regardless of the selected configuration, the propulsion system can be optimized to provide a peak efficiency at the relevant operating loads.

\subsection{Mass Sensitivity}

The mass sensitivity depends on the efficiency characteristics of the propulsion system. Assuming a constant propulsion efficiency of $11 \mathrm{~g} / \mathrm{W}$, a $1 \mathrm{~kg}$ change in mass gives a change in power consumption of $90.9 \mathrm{~W}$. That is the propulsion efficiency given for the U8II KV100 from T-motor at 50\% throttle [38]. At $40 \%$ throttle, it is $13.3 \mathrm{~g} / \mathrm{W}$, and at $90 \%$ throttle, it is $7.1 \mathrm{~g} / \mathrm{W}$, giving a $1 \mathrm{~kg}$ mass change a $75 \mathrm{~W}$ and $140 \mathrm{~W}$ impact, respectively. Thus, the propulsion efficiency and motor utilization degree can significantly impact the mass sensitivity, emphasizing the importance of an accurate propulsion power model.

Figure 8 was established by calculating gross endurance based on the propulsion power associated with a $10 \%$ and $20 \%$ mass reduction in take-off mass for the reference drone, and with a payload of $5 \mathrm{~kg}$. For the $10 \%(1.95 \mathrm{~kg})$ and $20 \%(3.9 \mathrm{~kg})$ mass reduction, the endurance gain was $16 \%$ and $36 \%$, respectively, which is $13 \mathrm{~min}$ and $30 \mathrm{~min}$ for the $7.2 \mathrm{~L}$ configuration. About $1 \mathrm{~min}$ flight endurance can be gained for a $165 \mathrm{~g}$ mass reduction. The $5 \mathrm{~kg}$ payload gives a $28 \%$ reduction in endurance, which is $23 \mathrm{~min}$ for the $7.2 \mathrm{~L}$ configuration giving a take-off mass of $24.6 \mathrm{~kg}$, and bringing the power consumption up from $2154 \mathrm{~W}$ to $2992 \mathrm{~W}$. This illustrates the importance and impact of mass and mass savings on the performance. Analyzing performance in limit scenarios is important for identifying the operational envelope.
Fig. 8 Mass sensitivity of the reference drone and fuel cell hybrid system. For the $7.2 \mathrm{~L}$ cylinder configuration and $11.1 \mathrm{~kg}$ energy system, the takeoff mass is $19.6 \mathrm{~kg}$

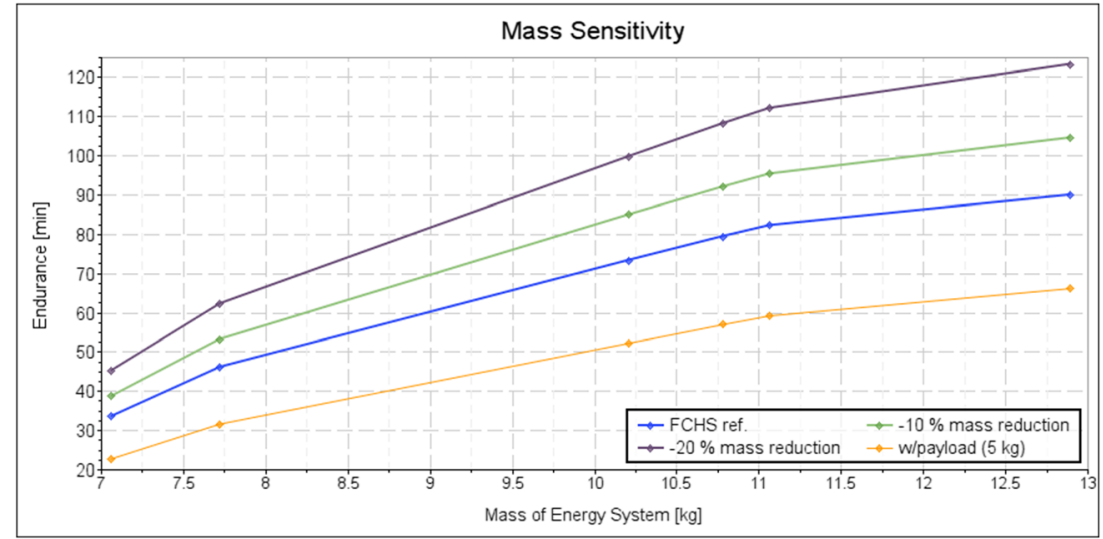


Weight reductions could come from a more lightweight airframe, cables, connectors, motors, electronics, and other improvements of fixed components [39]. However, the design will still have to be robust and handle relevant imposed vibrations with minimum deflections. Mass savings on a fuel cell hybrid system can be related to improved integration of the fuel cell stack and pressure vessel into the airframe, more lightweight pressure vessel, or lower degree of hybridization and smaller hybrid battery. Reduction in power consumption from mass savings can allow for using a fuel cell stack with a lower power rating, saving further mass. There are also interesting approaches where the hybrid system and energy storage also have a structural role, giving further savings. For a small multirotor, it was found that integrating the batteries in the structure could give a theoretical $41 \%$ increase in endurance [40]. The location of a mass saving is of importance. A mass saving on the drone will benefit all energy systems, while if related to the energy system, it will improve the specific energy of that system and improve the relative performance.

\subsubsection{Ideal Energy System Mass Fraction}

When analyzing various energy systems and system configurations, it is interesting to know the ideal energy system mass fraction. This refers to take-off mass, and a weight fraction of 0.5 on a drone with a take-off mass of $17 \mathrm{~kg}$ will have an empty mass of $8.5 \mathrm{~kg}$ and an energy system of $8.5 \mathrm{~kg}$. Figure 9 is based on Fig. 4, but the energy system mass fraction is used on the $\mathrm{x}$-axis. The peak endurance is reached at a 0.67 weight fraction, giving an energy system of $17 \mathrm{~kg}$. Beyond this point, the effective endurance is reduced. This energy system mass is relatively high and will, in many cases, not be practical to carry. There should also be some payload capacity, reducing the available mass fraction for the energy system to stay within maximum take-off mass limits.
One interesting finding is that even though the different specific energies will give different endurance, the endurance curves' characteristics and peak endurance are similar. The peak endurance and general shape of the curves are determined by the propulsion system response to the mass increase and associated propulsion efficiency. The endurance gain is relatively marginal towards peak endurance, and the curve turning point is probably a better indicator of the ideal energy system mass. Further research could look into how the ideal energy system mass can be identified in general for various multirotor drones and energy system characteristics. Research carried out by L. Traub [41] found the optimal battery weight fraction for fixed-wing UAV maximum range and endurance at cruise conditions to be $2 / 3$ of the total mass. M. Gatti [42] also found similar indications for multirotor drones. Traub states that in most cases, other practical concerns related to take-off mass, payload capacity, maneuverability or operating limitations would dictate the maximum battery size.

\subsection{Specific Energy}

The gravimetric energy density, specific energy, is an important factor when comparing energy systems. If an energy system has a higher specific energy, the same amount of energy can be carried at a lower mass, giving a secondary endurance or payload capacity benefit. Alternatively, more energy can be carried for the same mass, also increasing endurance. To increase the specific energy, the energy system's mass can be reduced, or the energy amount can be increased. The specific energy of a fuel cell hybrid system is:

$\varepsilon_{S . F C H S}=\frac{E_{F C}+E_{h . b a t t}}{m_{F C}+m_{H_{2}}+m_{h . b a t t}}$

where the $E_{F C}$ is fuel cell system energy, $E_{h \text {. batt }}$ is hybrid battery energy, $m_{F C}$ is the mass of the fuel cell stack and
Fig. 9 Gross endurance as a function of energy system mass fraction. The empty mass is $8.5 \mathrm{~kg}$. Peak endurance is reached at a 0.67 weight fraction, with an energy system of $17.2 \mathrm{~kg}$ and a take-off mass of $25.7 \mathrm{~kg}$




balance of plant, $m_{H 2}$ is hydrogen storage mass and $m_{h \text {. batt }}$ is hybrid battery mass. The reference FC hybrid system's specific energy ranges from $124 \mathrm{Wh} / \mathrm{kg}$ to $284 \mathrm{Wh} / \mathrm{kg}$. The fuel cell system's specific energy can be higher than that of the hybrid battery, so in most cases, it is beneficial for the overall specific energy that the hybrid battery is as small and lightweight as possible. This minimum size is limited by 1) energy buffer for emergency landings, and 2) the design nominal and peak power, which is related to battery discharge rate and the design operational envelope and associated power consumption profile. There has also been some research about hybrid systems using supercapacitors to achieve the required performance at a lower mass of the hybrid component. This can improve load smoothing, fuel cell efficiency, and durability [43-46].

\subsubsection{Improved Batteries}

Battery performance is evolving rapidly, and the specific energy is likely to improve in the next years. As this happens, the benefit threshold relative to fuel cell hybrid systems will be affected, and batteries will become more competitive at high energy levels. However, it is important to note that fuel cell hybrid systems also will benefit from improved battery performance, and the exact impact will depend on the hybrid battery energy requirement and associated mass savings. In Fig. 10, the gross endurance plot for the reference FCHS is modified for three improved battery specific energies, assuming a constant degree of hybridization of $17 \%$.

The performance threshold between batteries and FCHS is moved from $7.4 \mathrm{~kg}$ with $180 \mathrm{Wh} / \mathrm{kg}$ batteries to $8.5 \mathrm{~kg}$ with $350 \mathrm{Wh} / \mathrm{kg}$, so the impact on the threshold is not that large. The endurance improvement for the battery-powered system, however, is quite significant. For an $8.5 \mathrm{~kg}$ energy system, the endurance is doubled. Instead of performing between the $2 \mathrm{~L}$ and $3 \mathrm{~L}$ fuel cell system, it approaches the $7.2 \mathrm{~L}$ fuel cell system.
Even though the specific energy of new batteries improves, they must provide an adequate discharge rate. Because of the coupling between capacity and power, they can have challenges with providing sufficient power at the relevant energy levels and might not be suitable for high power applications.

\subsubsection{Higher H2 Pressure}

The effective energy $E_{F C}$ from the fuel cell system as a function of storage pressure $p$ and cylinder volume $V_{c y l}$ can be calculated according to the following equation [27]:

$E_{F C}\left(p, V_{c y l}\right)=\rho_{H_{2}}(p) \cdot V_{c y l} \cdot h_{H_{2}} \cdot \eta_{F C} \cdot \eta_{H_{2}}$

where $\rho_{H 2}(\rho)$ is the hydrogen density as a function of pressure, $V_{c y l}$ is the internal cylinder volume, $h_{H 2}$ is the specific enthalpy of hydrogen (LHV), $\eta_{F C}$ is the fuel cell efficiency, and $\eta_{H 2}$ is the hydrogen utilization. The fuel cell efficiency is typically $50 \%$ and can be assumed to be constant. Factors like load dynamics, membrane hydration, and cell temperature have an impact on efficiency. The hydrogen utilization can be assumed to be $98 \%$, but if there are leaks or high amounts of gas is purged, the utilization is lower.

The most common cylinder type used on drones is Class IV, carbon fiber composite cylinders with a polymer liner. They are relatively lightweight and can typically store 300 bar of hydrogen. With EN 12245 certification, they have a safety factor of 1.5 , is tested at 450 bar, and have a nonlimited life (NLL) from a design perspective. There are also other certification standards like DOT, ISO, TPED, and more. There are also lightweight cylinders with a lower safety factor and limitations to the number of fills and fill frequency. They will not store more hydrogen but can give a mass saving.

The density of hydrogen at $300 \mathrm{bar}, 450 \mathrm{bar}$, and $700 \mathrm{bar}$ is $20.8 \mathrm{~g} / \mathrm{L}, 28.8 \mathrm{~g} / \mathrm{L}$, and $39.7 \mathrm{~g} / \mathrm{L}$. Even though the density is not linear to the pressure increase, the amount of hydrogen at
Fig. 10 Impact on gross endurance for the reference FCHS system with specific energies of $180 \mathrm{Wh}, 250 \mathrm{Wh}, 300 \mathrm{Wh}$, and $350 \mathrm{Wh}$ compared to the batteryonly performance

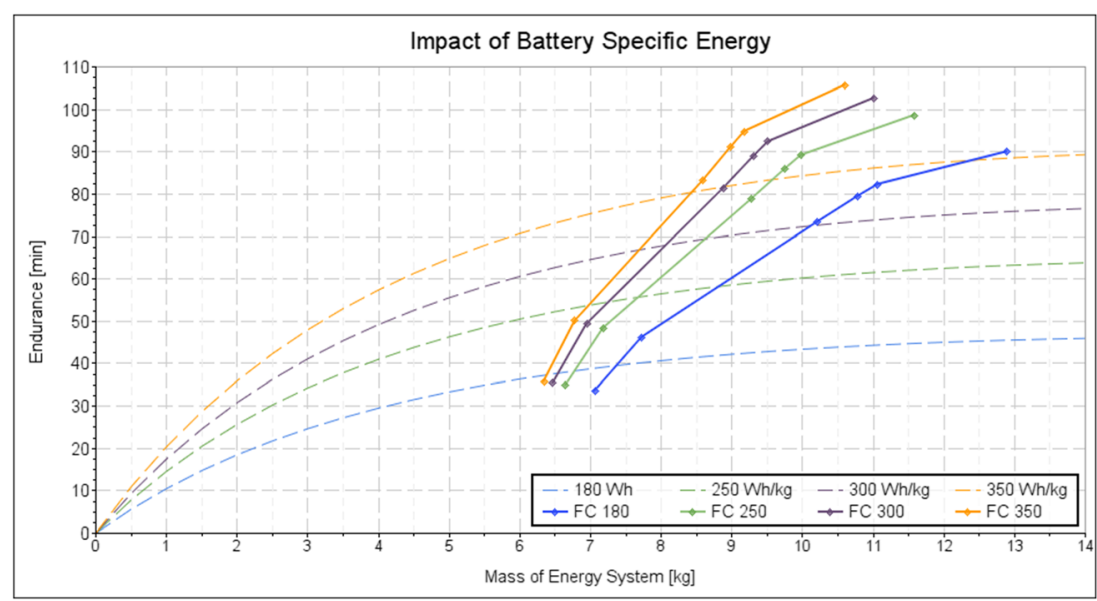


700 bars is almost double that of 300 bar. However, with higher pressure comes some additional cylinder mass. There are not many cylinders for 450-700 bar pressure commercially available, but they can be custom made from manufacturers like Sinoma. The reduction valve also has to be upgraded so it can reduce the pressure to the 1 bar hydrogen at a sufficient flowrate that is needed for the fuel cell, typically about $15 \mathrm{~L} /$ min pr. kW. The higher pressure can also lead to some additional risk in the case of a ground impact.

Using Eq. (4) to calculate effective energy, the CTS cylinders' specific energy is in the range of $554 \mathrm{Wh} / \mathrm{kg}$ to $787 \mathrm{Wh} /$ $\mathrm{kg}$, not including the regulator. It should be noted that the smaller cylinders are less efficient, which is in part related to the fixed mass of the cylinder boss, which is similar for all vessels.

The impact on endurance from some different cylinder options and storage pressures is illustrated in Fig. 11. The degree of hybridization is kept at $17 \%$, which scales the hybrid battery with hydrogen energy and have some impact on the response. Due to limitations in commercially available cylinder options, some assumptions regarding cylinder mass are made.

The $300 \mathrm{LW}$ cylinders are slightly lighter, but they contain the same amount of hydrogen. Thus, the endurance of the smaller cylinders is about the same. The mass savings influence the power consumption for the larger cylinders, and an endurance gain of $7 \mathrm{~min}$ can be achieved for the $9 \mathrm{~L}$ cylinder.

The 450 bar cylinders are heavier, but the energy stored is also higher, giving a higher initial endurance. The $6 \mathrm{~L}$ cylinder at 450 bar gives about the same endurance as the $9 \mathrm{~L}$ at 300 bar. The 700 bar gives an even higher initial endurance, and the $3 \mathrm{~L}$ cylinder option gives the same endurance as the $6 \mathrm{~L}$ at $300 \mathrm{bar}, 72 \mathrm{~min}$. This can give a considerable advantage in situations where volume for integration is scarce. The endurance jumps between cylinders are quite large, and a superior endurance can be achieved from the $6 \mathrm{~L}$ cylinder and up. The mass at this point, however, starts to become relatively high. For the $9 \mathrm{~L}$ option at both 450 bar and 700 bar, the added mass catches up, and the endurance gain is minimal.

\subsubsection{Degree of Hybridization}

The relative contribution of a secondary power source in a hybrid system is defined by the degree of hybridization $\beta$ [47]. For $\beta=0$, the fuel cell provides all power. As $\beta$ increase, the battery contribution become higher. In the reference fuel cell hybrid system, the hybrid degree is $\beta=0.17$.

The gross endurance for various degrees of hybridization is presented in Fig. 12. A constant specific power of $526.3 \mathrm{~W} / \mathrm{kg}$ is assumed for the fuel cell stack, which corresponds with $3.8 \mathrm{~kg}$ for the $2 \mathrm{~kW}$ reference system. As the hybridization degree change, the stack power and mass changes. Commercial offthe-shelf stack power levels are limited, but custom stacks can be requested. The fuel cell hybrid system has $1.1 \mathrm{~kg}$ of auxiliary equipment, and the hydrogen cylinder mass ranges from $1.2 \mathrm{~kg}$ to $3.8 \mathrm{~kg}$ for the relevant cylinders. The hybrid battery energy $E_{h . ~ b a t t}$ is a function of the fuel cell system energy $E_{F C}$, and can be calculated [27]:

$E_{\text {h.batt }}\left(E_{F C}\right)=\frac{\beta}{1-\beta} \cdot E_{F C}+\left(t_{\text {emc }} \cdot P_{F C H S}\right)$

The electric energy from the fuel cells and hydrogen storage $E_{F C}$ is calculated from Eq. (4). An energy buffer to handle an emergency landing is also included, where the full power $P_{F C H S}$ can be maintained for $t_{e m c}=2 \mathrm{~min}$.

The specific energy of the $3 \mathrm{~L}$ fuel cell system with $\beta=0$ is $152 \mathrm{Wh} / \mathrm{kg}$, which is just above the $144 \mathrm{Wh} / \mathrm{kg}$ battery

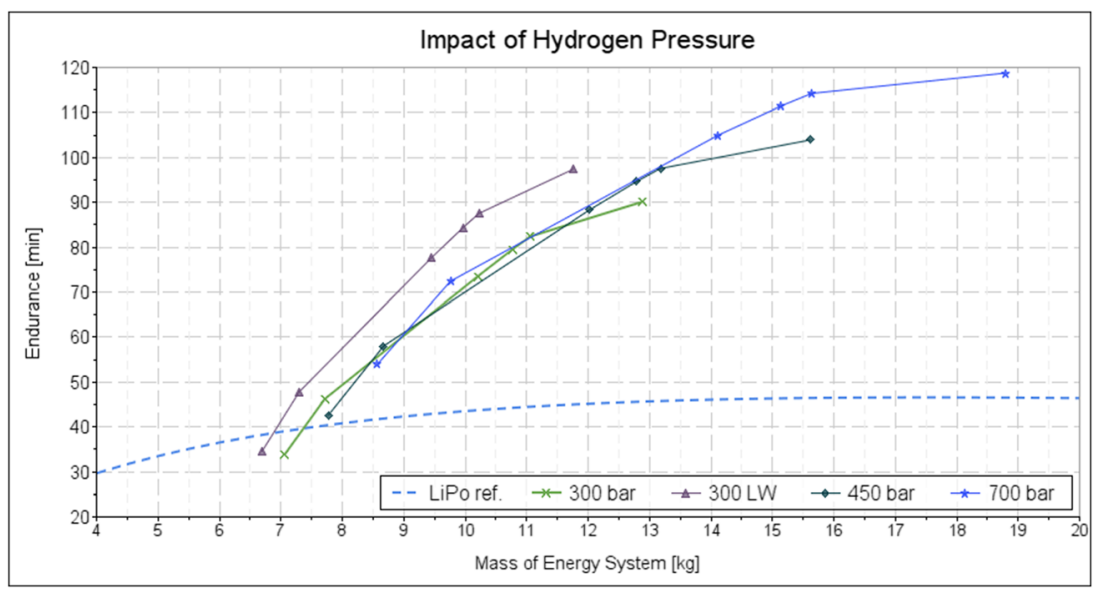

Fig. 11 The impact on the endurance of various storage pressures and associated pressure vessels. The LiPo reference curve is based on a $144 \mathrm{Wh} / \mathrm{kg}$ effective specific energy. The 300 bar cylinders are based on the reference cylinders from CTS: $2 \mathrm{~L}, 3 \mathrm{~L}, 6 \mathrm{~L}, 6.8 \mathrm{~L}, 7.2 \mathrm{~L}$, and
9 L. The $300 \mathrm{LW}$ cylinder is $30 \%$ lighter than the certified 300 bar cylinders, and the 450 bar cylinders are $30 \%$ heavier. The 700 bar cylinder is based on data from the manufacturer Sinoma [2], having a specific energy of $960 \mathrm{Wh} / \mathrm{kg}$ 
Fig. 12 Fuel cell hybrid system with different degree of hybridization $\beta$ for the $2 \mathrm{~L}-9 \mathrm{~L}$ CTS cylinder range

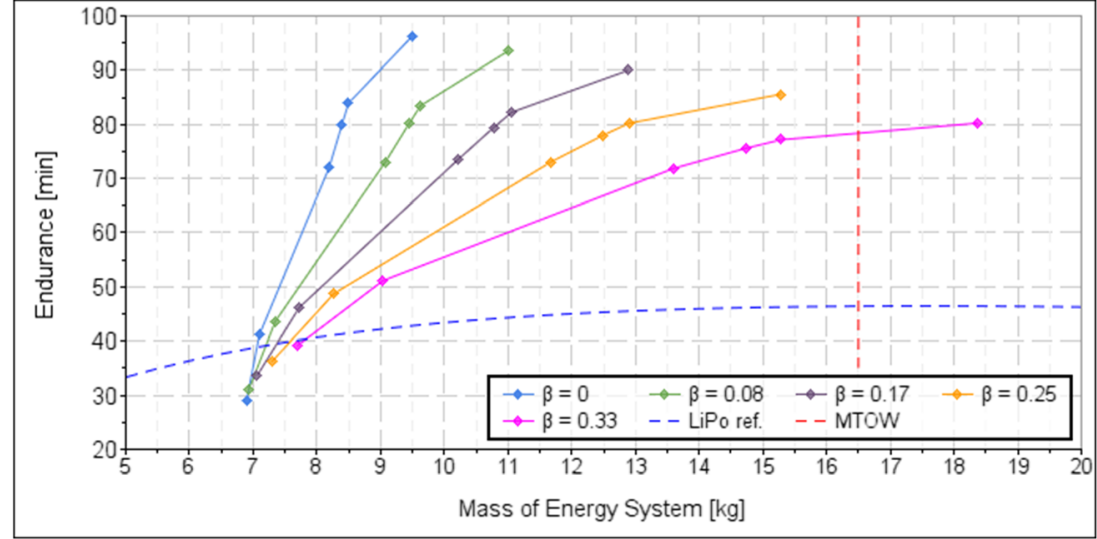

reference value, assuming $80 \%$ depth-of-discharge. With the highest hybridization $(\beta=0.33)$, the $3 \mathrm{~L}$ system has a specific energy of $191 \mathrm{Wh} / \mathrm{kg}$, and the endurance is improved by $10 \mathrm{~min}$. However, for the 7.2 L system, the specific energy is reduced as hybridization increases. For the $\beta=0.17$ case, the impact of the hybrid battery is a $2.5 \mathrm{~kg}$ mass increase and a 1.6-min reduction in endurance, compared to the $\beta=0$ case.

Thus, for the small cylinder configurations with limited energy and endurance $(<144 \mathrm{Wh} / \mathrm{kg})$, higher degrees of hybridization can improve the endurance. As the cylinder volume and energy increase, higher degrees of hybridization increase the overall system mass and can reduce endurance. Thus, for high-energy fuel cell systems, it can be beneficial to limit hybridization. This relates to the constant specific energy of batteries and variable specific energy of fuel cell systems, and how they contribute to the overall specific energy through mass and energy (Eq. (3)).

However, it must be noted that for the relevant fuel cell type, a hybrid battery must be present to sustain nominal operation through hydration purge cycles and manage peak loads. For small batteries, the power criteria are often the driving criteria. A maximum discharge rate of $5 \mathrm{C}$ will give a minimum capacity of $10.8 \mathrm{Ah}$ at the relevant voltage and power levels, while the energy needed for a two-minute emergency landing is only $1.8 \mathrm{Ah}$.

\section{Further Fuel Cell Adoption}

While analysis of performance threshold and parameter sensitivity is important, several perspectives need to align to ensure increased industrial adoption of fuel cell powered multirotor drones. The most critical barriers are related to technical, regulatory, and operational aspects [5].

\subsection{Technical Readiness}

Much of the current activities in the fuel cell market are about demonstrating performance, which is the key value proposition, and relevant use-cases where the improved endurance provides more efficient operations or inspections. Still, according to publicly available data, it does not appear that any fuel cell powered multirotor drones are well proven in operational environments over time, which corresponds to Technology Readiness Level 9. It will be necessary for potential fuel cell integrators and users to have operational and financial rewards well documented and proven. Operational requirements and experience will also further help to advance the state-of-technology.

In terms of technical improvements, the regulatory developments will drive some new requirements and facilitate a closer integration into the multirotor drones. Sharif and Orhan [48] have detailed the status and research potential for PEM fuel cells. Gong and Verstraete [4] focus on the status and research needs for fixed-wing UAV-specific fuel cell systems, and their recommendations on relevant research topics are; improvements in hydrogen storage, operational robustness, hydration management, and hybridization and power management strategies.

\subsection{Regulatory Barriers}

A basic premise for further adoption is that fuel cell powered drones must be legal to operate where they are needed to be operated. Because the fuel cell hybrid system is a critical part of the propulsion system, it is central to the drone's overall airworthiness. The question is if fuel cell based power plants must be certified according to EASA aviation standards and have a type certificate [49], or if product certification (CE) is sufficient. The main factors driving the level of certification are the level of risk associated with the stored hydrogen and if the most relevant operations and use-cases will fall within the 'Certified' category.

As the hydrogen fuel is an integrated part of the power plant and not a payload, it is, by definition, not 'dangerous goods', which would trigger the need for type certification. However, the risks must be adequately mitigated, and the operation will have to be defined through a CONOPS 
(concept of operations) and a SORA (specific operation risk assessment). As most relevant use-cases will include beyond visual line-of-sight and operations close to urban or populated areas, a type-certified propulsion system will give the best operational flexibility. But it will also be a significant cost driver as strict technical requirements and proving compliance is a comprehensive undertaking.

\subsection{Operational Barriers}

Supply-chain and logistical requirements will affect the mobility and complexity of the operation. Thus, the operational concept and use-case must align with reasonable logistical solutions. To ensure safe and proper hydrogen handling, fuel cell installation, and operations, the relevant personnel must be well trained. Integrating and using a fuel cell hybrid system have some initial hardware, infrastructure, and training costs. Considering those cost factors, one study found that the cost per hour of flight for a fuel cell powered multirotor drone was 51 EUR, while battery-powered operations would be 4.30 EUR [27]. The fuel cell cost might drop as the market evolve, but more strict airworthiness requirements may further increase cost levels.

Justifying additional cost and complexity by achieving a return-on-investment is critical for operators. It is expected that as more data on actual operations are gathered, the usecases that best align with value creation will pave the way for further adoption. However, fuel cell powered multirotors are not expected to replace all battery-powered drones and will probably not be viable for all operations.

\section{Summary and Concluding Remarks}

A sensitivity analysis is carried out to identify the impact of central system parameters for a multicopter fuel cell hybrid system (FCHS). There is limited research on such lightweight high-power systems for multirotor drone applications of this scale, and this paper contributes with an analysis that is useful for system design, targeting improvements, and optimization. To increase technology adoption, it is essential that knowledge on how to achieve ideal performance is known to the fuel cell drone community.

Thrust stand test data is used to establish an empirical propulsion system model that improves the analysis's validity. Gross endurance is used as the main parameter, and the impact of propulsion system configuration and efficiency, take-off mass, improvements in hydrogen storage, and how improved battery performance impact the FCHS benefit threshold is studied.

There are many aerodynamic and mechanical factors that influence the overall propulsion efficiency. Different configurations will have different number of motors, propeller size, and disk loading. The motor and propeller combination must be matched to provide peak efficiency at the relevant operating loads. Thrust stand data shows a $20-30 \%$ loss in propulsion efficiency due to the coaxial propeller configuration. At $25 \mathrm{~kg}$ thrust, that amounts to a $700 \mathrm{~W}$ power difference between a coaxial and single octocopter propulsion system configuration. Lower propulsion power in nominal flight can also allow for the use of a smaller fuel cell system that will provide additional weight and endurance benefits. There are also other practical considerations concerning overall physical size and redundancy to consider.

In terms of take-off weight, a $10 \%(1.95 \mathrm{~kg})$ mass reduction will improve the endurance by $16 \%$, which is $13 \mathrm{~min}$ for the $7.2 \mathrm{~L}$ configuration. With improvements in battery specific energy from $180 \mathrm{Wh} / \mathrm{kg}$ to $350 \mathrm{Wh} / \mathrm{kg}$, the performance threshold between batteries and FCHS is moved from $7.4 \mathrm{~kg}$ to $8.5 \mathrm{~kg}$. That is not significant, but the analysis demonstrates that it is important to consider that battery improvements also benefit the FCHS. Concerning hydrogen storage, a lightweight cylinder can be beneficial for large cylinder volumes. That is because the energy does not change, but mass savings give an endurance benefit. If a 450 bar cylinder is used, a $6 \mathrm{~L}$ cylinder can replace a $9 \mathrm{~L}$ one at 300 bar. A 700 bar cylinder will somewhat increase the risk, but if the overall system volume is of the highest importance, even a $3 \mathrm{~L}$ cylinder can provide a 72-min endurance.

The state-of-technology is presented, and it is shown that several demonstrations have verified the performance and confirmed the viability of powering multirotor drones with fuel cells. However, the technology does not appear to have been fully proven in operational environments. To achieve further adoption, more data and experience from actual operations in relevant environments should be obtained. Operational requirements will also help drive further improvements, and it will aid the understanding of how operational and logistical concepts can align to form compelling use-cases that give the best operational and financial rewards. In terms of regulations, it will be important to clarify certification requirements, as this can have a significant impact on the fuel cell drone market.

Continued efforts should be targeted towards improving and optimizing fuel cell hybrid systems in terms of mass and performance. Further research could look at specific mission profiles and analyze the impact of FCHS on the operational envelope and provide net endurance estimates.

Acknowledgments The authors would like to thank Nordic Unmanned $\mathrm{AS}$ and the Norwegian Research Council for the support. Also, thanks to the students that were involved in the thrust stand measurements.

Author's Contributions Jørgen Apeland has prepared the material, carried out data analysis, and written the original draft. All authors contributed to 
research conceptualization, reviews, and final editing. Dimitrios Pavlou and Tor Hemmingsen have supervised the project. All authors have read and approved the final manuscript.

Funding Open access funding provided by the University of Stavanger. The research is funded by the Norwegian Research Council and Nordic Unmanned AS under project number 286603.

Data Availability All underlying data and calculations are available upon request.

\section{Declarations}

Ethical Approval Not applicable.

Consent to Participate Not applicable.

Consent to Publish The authors and relevant institutions approve publishing this research.

Competing Interests Jørgen Apeland is employed by Nordic Unmanned AS, the main stakeholder of the project. The authors declare no further relevant financial or non-financial interests.

Open Access This article is licensed under a Creative Commons Attribution 4.0 International License, which permits use, sharing, adaptation, distribution and reproduction in any medium or format, as long as you give appropriate credit to the original author(s) and the source, provide a link to the Creative Commons licence, and indicate if changes were made. The images or other third party material in this article are included in the article's Creative Commons licence, unless indicated otherwise in a credit line to the material. If material is not included in the article's Creative Commons licence and your intended use is not permitted by statutory regulation or exceeds the permitted use, you will need to obtain permission directly from the copyright holder. To view a copy of this licence, visit http://creativecommons.org/licenses/by/4.0/.

\section{References}

1. Mi, C., Masrur, M.A.: Electric Energy Sources and Storage Devices. In: Hybrid Electric Vehicles: Principles and Applications with Practical Perspectives. John Wiley \& Sons, Incorporated, Newark, UK (2018)

2. Fuel Cell Power For UAVs. www.intelligent-energy.com/ourproducts/uavs/. Accessed Feb 2020

3. Bradley, T., Moffitt, B., Fuller, T., Mavris, D., Parekh, D.: Design studies for hydrogen fuel cell powered unmanned aerial vehicles. In: 26th AIAA Applied Aerodynamics Conference 2008, p. 6413

4. Gong, A., Verstraete, D.: Fuel cell propulsion in small fixed-wing unmanned aerial vehicles: Current status and research needs. Int $\mathrm{J}$ Hydro Energy. 42(33), 21311-21333 (2017). https://doi.org/10. 1016/j.ijhydene.2017.06.148

5. Apeland, J., Pavlou, D., Hemmingsen, T.: State-of-Technology and Barriers for Adoption of Fuel Cell Powered Multirotor Drones. In: 2020 International conference on unmanned aircraft systems (ICUAS), Athens, Greece 2020, pp. 1359-1367

6. O'Hayre, R., Cha, S.-W., Colella, W.G., Prinz, F.B.: Fuel Cell Fundamentals, 3rd ed. John Wiley \& Sons, New Jersey (2016)

7. Larminie, J., Dicks, A.: Fuel Cell Systems Explained, 2nd edn. John Wiley \& Sons, Chichester (2003)
8. Hassanalian, M., Abdelkefi, A.: Classifications, applications, and design challenges of drones: A review. Prog Aerospace Sci 91, 99 131 (2017). https://doi.org/10.1016/j.paerosci.2017.04.003

9. Aerostak Ultra-light Fuel Cells. www.hes.sg/. Accessed Feb 2020

10. UAV Hydrogen Fuel Cell System. www.mmcuav.com/portfolioitems/hydrogen-fuel-cell-system/. Accessed Feb 2020

11. FCair UAV Fuel Cell Power Solutions. www.ballard.com/markets/ uav. Accessed Feb 2020

12. DP30 Powerpack. www.doosanmobility.com/en/technology/tech 01/. Accessed Feb 2020

13. Protium Fuel Cells. www.spectronik.com/fuel-cell/. Accessed Feb 2020

14. H3 Dynamics delivers first hydrogen powered UAS for US Navy. Fuel Cells Bulletin 2019(12), 4-5 (2019). doi:www.doi.org/ $10.1016 /$ S1464-2859(19)30504-8

15. Intelligent Energy module provides up to $1.6 \mathrm{~kW}$ for UAVs. Fuel Cells Bulletin 2019(4), 5 (2019). doi:www.doi.org/10.1016/S14642859(19)30141-5

16. Intelligent Energy launches $2.4 \mathrm{~kW}$ fuel cell module for UAVs. Fuel Cells Bulletin 2019(5), 6 (2019). doi:www.doi.org/10.1016/ S1464-2859(19)30189-0

17. Intelligent Energy powers two multirotor UAVs to new records. Fuel Cells Bulletin 2019(2), 5-6 (2019). doi:www.doi.org/ 10.1016/S1464-2859(19)30051-3

18. Ball, M.: Fuel Cell Module Powers Record-Breaking UAV. www. unmannedsystemstechnology.com/2019/04/intelligent-energyfuel-cell-module-powers-record-breaking-uav/ (2019). Accessed Feb 2020

19. Osenar, P., Sisco, J., Reid, C.: Advanced Propulsion for Small Unmanned Aerial Vehicles. In. BALLARD White Paper, (2017)

20. Sisco, J., Robinson, P.: Fuel Cell Powered UAS: Hydrogen Safety, Handeling, and Field Experience. In: AUVSI Xponential, Chicago 2019

21. Sisco, J., Harrington, F., Robinson, P.: Hydrogen Fuel Cells for UAVs: Refueling Developments. In. BALLARD White Paper, (2018)

22. Sisco, J.: New Fuel Cell Technologies Extend Missions for Vertical Take-off and Landing Unmanned Aerial Vehicles. In: AUVSI Xponential, Dallas 2017

23. McNabb, M.: Doosan Fuel Cell Drone Makes 43 Mile Medical Delivery. www.dronelife.com/2019/11/15/doosan-fuel-cell-dronemakes-43-mile-medical-delivery/ (2019). Accessed Feb 2020

24. Hydrogen-Powered Drones to Inspect Gas Pipeline. www. uasvision.com/2020/02/05/hydrogen-powered-drones-to-inspectgas-pipeline/ (2020). Accessed Feb 2020

25. Doosan Drone Wins Two Honours at CES 2020 Awards. www.eu. doosanequipment.com/en/news/2020-21-01-doosan-droneces2020-awards (2020). Accessed Feb 2020

26. Staaker BG200. www.nordicunmanned.com/products/unmannedsystems-drones/staaker-bg200/. Accessed Feb 2021

27. Apeland, J., Pavlou, D., Hemmingsen, T.: Suitability Analysis of Implementing a Fuel Cell on a Multirotor Drone. Journal of Aerospace Technology and Management 12 (2020). https://doi. org/10.5028/jatm.v12.1172

28. CTS Cylinders. www.ctscyl.com/prodotti/h2. Accessed Feb 2021

29. Gong, A., Verstraete, D.: Role of battery in a hybrid electrical fuel cell UAV propulsion system. In: 52nd Aerospace Sciences Meeting 2014

30. Verstraete, D., Gong, A., Lu, D.D.C., Palmer, J.L.: Experimental investigation of the role of the battery in the AeroStack hybrid, fuelcell-based propulsion system for small unmanned aircraft systems. Int J Hydro Energy. 40(3), 1598-1606 (2015). https://doi.org/10. 1016/j.ijhydene.2014.11.043

31. Donateo, T., Ficarella, A., Spedicato, L., Arista, A., Ferraro, M.: A new approach to calculating endurance in electric flight and 
comparing fuel cells and batteries. Applied Energy. 187, 807-819 (2017). https://doi.org/10.1016/j.apenergy.2016.11.100

32. Leishman, J.G., Ananthan, S.: Aerodynamic optimization of a coaxial proprotor. In: annual forum proceedings-American helicopter society, Phoenix 2006, vol. 1. American helicopter society, INC

33. Prior, S.: Optimizing Small Multi-Rotor Unmanned Aircraft: a Practical Design Guide. CRC Press, (2018)

34. Hidle, S.R., Ingebretsen, V.B.: Improvement of Efficiency of a Coxial Octodrone. BSc Thesis, University of Stavanger (2020)

35. Series 1780 Dynamometer Datasheet. www.rcbenchmark.com. Accessed Sept 2020

36. Scicluna, L., Sant, T., Farrugia, R.N.: Investigation of wind flow conditions on the flight endurance of UAVs in hovering flight: A preliminary study. In: ASME 2019 2nd International Offshore Wind Technical Conference 2019

37. Quan, Q.: Introduction to multicopter design and control. Springer Singapore. (2017)

38. T-Motor U8II KV100 Specifications. www.t-motor.com. Accessed Sept 2020

39. Dagur, R., Singh, D., Bhateja, S., Rastogi, V.: Mechanical and material designing of lightweight high endurance multirotor system. Materials Today: Proceedings 21, 1624-1631 (2020). https:// doi.org/10.1016/j.matpr.2019.11.251

40. Hollinger, A.S., McAnallen, D.R., Brockett, M.T., DeLaney, S.C., Ma, J., Rahn, C.D.: Cylindrical lithium-ion structural batteries for drones. International Journal of Energy Research (2019). https:// doi.org/10.1002/er.4937

41. Traub, L.W.: Optimal Battery Weight Fraction for Maximum Aircraft Range and Endurance. J. Aircraft 53(4), 1-3 (2016). doi: https://doi.org/10.2514/1.C033416

42. Gatti, M., Giulietti, F., Turci, M.: Maximum endurance for batterypowered rotary-wing aircraft. Aerospace Sci. Technol. 45, 174-179 (2015). https://doi.org/10.1016/j.ast.2015.05.009

43. Odeim, F., Roes, J., Heinzel, A.: Power Management Optimization of an Experimental Fuel Cell/Battery/Supercapacitor Hybrid System. Energies. 8(7), 6302-6327 (2015). https://doi.org/10. 3390/en8076302

44. Lei, T., Yang, Z., Lin, Z., Zhang, X.: State of art on energy management strategy for hybrid-powered unmanned aerial vehicle. Chinese Journal of Aeronautics (2019). https://doi.org/10.1016/j. cja.2019.03.013

45. Ettihir, K., Boulon, L., Agbossou, K.: Optimization-based energy management strategy for a fuel cell/battery hybrid power system. Appl. Energy. 163, 142-153 (2016). https://doi.org/10.1016/j. apenergy.2015.10.176

46. Gong, A., MacNeill, R., Verstraete, D., Palmer, J.L.: Analysis of a Fuel-Cell/Battery/Supercapacitor Hybrid Propulsion System for a
UAV using a Hardware-in-the-Loop Flight Simulator. In: 2018 AIAA/IEEE electric aircraft technologies symposium. Am Inst. Aeronautics Astronautics, (2018)

47. Mi, C., Masrur, M.A.: HEV Fundamentals. In: Hybrid Electric Vehicles: Principles and Applications with Practical Perspectives. John Wiley \& Sons, Incorporated, Newark, UK (2018)

48. Sharaf, O.Z., Orhan, M.F.: An overview of fuel cell technology: Fundamentals and applications. Renew. Sustain. Energy Rev. 32, 810-853 (2014). https://doi.org/10.1016/j.rser.2014.01.012

49. EASA: CS - Light UAS Special Condition for Light Unmanned Aircraft Systems - Medium Risk. (2020)

Publisher's Note Springer Nature remains neutral with regard to jurisdictional claims in published maps and institutional affiliations.

Jørgen Apeland holds a M.Sc. degree in Mechanical Engineering from the Norwegian University of Science and Technology and a B.Sc. from the Western Norway University of Applied Sciences within the same field. He is enrolled in an Industrial-PhD program at the University of Stavanger, with Nordic Unmanned as industrial partner. The research topic is application of fuel cell based propulsion systems to extend multirotor drone endurance.

Dimitrios Pavlou is a Professor in the Department of Mechanical and Structural Engineering and Materials Science at the University of Stavanger in Norway. In 2014 he was elected a full member of the Norwegian Academy of Technological Sciences. He has had twenty years of teaching and research experience in the fields of applied mechanics, fracture mechanics, finite and boundary elements, structural dynamics, composite materials, and pipeline technology. Prof. Pavlou has authored five books. He is associate editor in 3 international journals, member of the editorial board in 5 international journals, and reviewer in more than 30 ones.

Tor Hemmingsen has near 40 years experience in research, education and management, related to chemistry, corrosion and oil and gas industry. He has been employed to University of Stavanger and University of Tromsø. Since 2007 he has been a full professor in Corrosion and Electrochemistry, and 2011-15 Prorector at University of Stavanger. He has been Department Heads of Mathematics and Natural Sciences 20002008 and Department for Mechanical and Structural Engineering and Materials Science 2016-23. He has been Board member of EuChemMS 2006-10, and President in Norwegian Chemical Society 2005-14. He has authored more than 70 international papers and supervised more than 100 student theses. 